Ann. Biol. anim. Bioch. Biophys., I976, 16 (I), 43-69.

\title{
INTERRUPTION DE LA CROISSANCE DU RAT PAR SOUS-NUTRITION ÉNERGÉTIQUE PENDANT DES DURÉES ATTEIGNANT DEUX ANS. REPRISE DE LA CROISSANCE ET DE LA MULTIPLICATION GELLULAIRE
}

\author{
G. DURAND \\ avec la collaboration technique de Noëlle Bourgeaux \\ Station de Recherches de Nutrition, \\ Centre national de Recherches zootechniques, I. N. R. A., \\ 78350 Jouy en Josas
}

\section{RÉSUMÉ}

Des lots de rats mâles sont soumis à une réduction sévère de l'apport énergétique de la ration (glucides et lipides), à partir du poids de $70 \mathrm{~g}$ (4 semaines) et empêchés de croître au-delà du poids de roo g, pendant 6,12 ou 24 mois. A la fin de chacune de ces périodes un lot est sacrifié, un autre est réalimenté. Les animaux empêchés de croître sont comparés à des témoins de roo $\mathrm{g}$ (même poids) et de $70 \mathrm{~g}$. Les animaux réalimentés sont sacrifiés lorsqu'ils atteignent le poids de $600 \mathrm{~g}, \mathrm{ou}, \mathrm{a}$ défaut, lorsqu'ils atteignent leur poids maximal; ils sont comparés à des témoins de $600 \mathrm{~g}$.

Le corps des animaux est partagé en 6 fractions : foie, muscles des membres postérieurs, peau, tissus adipeux, viscères + sang, carcasse. Le poids et les contenus en protéines, RNA et DNA de chacune de ces six fractions, sont mesurés; ces mesures permettent en particulier d'apprécier l'hyperplasie et l'hypertrophie cellulaires.

\section{I. - Animaux empêchés de croître}

- Du point de vue pondéral, et par rapport à la normale, la sous-alimentation énergétique favorise la musculature, les viscères et l'ensemble squelette + musculature (carcasse), mais défavorise le foie, la peau et surtout les tissus adipeux.

- Au plan des contenus protéiques, la sous-alimentation énergétique favorise le foie, la musculature, les viscères, l'ensemble squelette + musculature, défavorise les tissus adipeux; le contenu protéique de la peau reste équivalent chez les expérimentaux et les témoins de même poids.

- Alors que les contenus en RNA et DNA augmentent notablement chez les témoins passant de $70 \mathrm{~g}$ à Ioo $\mathrm{g}$, ils restent stables ou rétrogradent dans les tissus et organes des animaux dont la croissance est très ralentie entre $70 \mathrm{~g}$ et Ioo $\mathrm{g}$, puis stoppée à ce poids. Une carence énergétique très sévère provoque d'abord un arrêt de l'hyperplasie, qui peut être suivi à plus ou moins long terme d'une perte de cellules dans certains tissus, en particulier les tissus adipeux. 


\section{2. - Animaux réalimentés}

-- Après réalimentation, la croissance reprend dans tous les cas étudiés ; cependant, tandis que les rats préalablement carencés pendant six mois atteignent normalement le poids de $600 \mathrm{~g}$, les rats préalablement carencés pendant un an et deux ans ne dépassent pas les poids de $500 \mathrm{~g}$ et $420 \mathrm{~g}$ respectivement.

- Cette croissance tardive est accompagnée d'une reprise de l'accumulation de protéines : de ce point de vue, le rattrapage par rapport aux témoins est pratiquement total pour les animaux sous-alimentés pendant 6 mois ; il est incomplet, mais équivalent, lorsque la durée de la restriction s'étend sur un ou deux ans.

- De même l'accumulation de RNA et de DNA reprend dans tous les cas; le rattrapage est pratiquement total chez les animaux restreints pendant 6 mois; il n'est que partiel chez les animaux carencés pendant des durées plus longues. Mais quoiqu'il en soit, la capacité d'hyperplasie est conservée chez des rats prépubères empêchés de croître pendant environ les $3 / 4$ de la durée de vie moyenne normale de l'espèce.

\section{INTRODUCTION}

Les effets d'un arrêt ou d'un ralentissement de la croissance dus à une carence nutritionnelle de plus ou moins longue durée sur le développement futur ont fait l'objet, depuis le début du siècle, d'un certain nombre de travaux et d'enquêtes concernant 1'animal, et plus récemment, 1'Homme.

Les premiers travaux importants en cette matière, dus à OSBORNE et MENDEL (I9I4-I9I5), montrent que chez le rat sevré dont la croissance est retardée par des carences alimentaires de différents types, la capacité de croître n'est pas perdue à un âge ou la croissance est normalement achevée, c'est-à-dire vers 300 jours. Ainsi, d'après les données de ces auteurs, la reprise de croissance peut être observée chez des rats âgés de $55^{\circ}$ jours, alors que la durée de vie moyenne de ces animaux dans des conditions normales d'alimentation serait de 750 jours. Cela conduit OsBorne et MENDEL à penser que la capacité de croître est conservée aussi longtemps qu'elle n'a pas eu la possibilité de s'exercer, et à émettre, sans doute trop hâtivement, 1'hypothèse selon laquelle cette capacité n'est pas liée au poids ou à l'âge auxquels 1'arrêt de croissance est imposé.

McCAy et al. (I935) confirment que le pouvoir de croître est conservé chez des rats soumis à une carence sévère de l'apport énergétique de la ration jusqu'à un âge correspondant presque à la durée de vie moyenne de l'espèce ; toutefois, la taille finale des animaux préalablement carencés reste inférieure à la normale. Ces auteurs appellent par ailleurs l'attention sur le fait que la survie des animaux devient très aléatoire lorsque le maintien à poids constant ou en croissance ralentie est obtenu par la carence de certains facteurs, comme la vitamine A par exemple.

Contrairement aux auteurs précédents, WIDDOwSON et McCANCE (I963) affirment que le rat ne peut croître après l'âge de 300 jours. LISTER et MCCANCE (I965-Ig66I967) soutiennent qu'il existe également chez le Porc et chez le Cobaye un âge au-delà duquel aucune croissance n'est plus possible, mais qu'il n'en est pas de même chez le Poulet.

D'autres auteurs (BRown et GuTHRIE, I968; BARNEs et al., I968) indiquent que 
des rats, dont la croissance est temporairement ralentie ou interrompue par des carences nutritionnelles, ne peuvent atteindre, sous certaines conditions, ni la stature, ni le poids qui eussent été les leurs s'ils avaient été convenablement alimentés en permanence.

De même, WINICK et NoBlE (Ig66) avancent que des rats soumis après sevrage à une forte sous-alimentation globale pendant $2 \mathrm{I}$ jours seulement, puis réalimentés à volonté, ne peuvent atteindre un poids adulte normal et que les quantités de DNA, contenues dans leurs muscles et dans certains de leurs organes, sont définitivement amoindries.

Durand et al. (I969 a) et DURAND et PENOT (I970) montrent que la reprise de croissance est possible chez des Rats sevrés, maintenus au poids de 68 g uniquement par réduction de l'apport énergétique de la ration, même si l'arrêt de croissance s'étend sur I60 jours; la vitesse de croissance des animaux réalimentés est pratiquement équivalente à celle des témoins de même poids, et rien ne laisse prévoir que leur poids maximal doive être inférieur à la normale. Toutefois, parvenus au poids de $600 \mathrm{~g}$, les muscles des animaux réalimentés contiennent moins de DNA que ceux des témoins.

Finalement, il existe encore bien des divergences suivant les auteurs, et de nombreux points relatifs à la possibilité de reprise de croissance et, plus encore, aux modalités de celles-ci, restent dans l'ombre.

Le présent travail est consacré :

I $^{\circ}$ à l'étude de 1'inhibition de croissance chez des rats mâles soumis, après sevrage, à une restriction de l'apport énergétique de la ration, telle que leur poids ne puisse dépasser Ioo g pendant 6 mois, un an ou deux ans ;

$2^{\circ}$ à l'étude de la reprise de croissance lorsque ces animaux sont réalimentés à volonté.

Les observations portent sur l'évolution :

- du poids vif et de la consommation alimentaire,

- du poids frais et du contenu protéique de certaines fractions corporelles importantes,

- de la quantité en DNA, proportionnelle au nombre de cellules, et de la quantité en RNA, test de l'activité cellulaire, contenues dans ceś fractions corporelles.

\section{MATÉRIEL ETT MÉTHODES}

A. - Matériel animal (fig. I, tabl. I et 2)

On utilise neuf lots de $\mathrm{I} 2$ à 15 rats mâles Wistar, âgés de 28 jours et pesant $70 \mathrm{~g} \pm 2 \mathrm{~g}$.

- Un premier lot est sacrifié à $70 \mathrm{~g}$ et constitue le lot témoin IA.

- Deux lots reçoivent ad libitum un régime semi-synthétique équilibré contenant 13 p. 100 de protéines; la composition de ce régime, dit régime témoin, est consignée sur le tableau $\mathbf{I}$. L'un de ces lots est sacrifié au poids de ıoo g (lot témoin IIA), l'autre au poids de 6oo g (lot témoin IIIA).

- Les six autres lots sont soumis à une réduction de l'apport des éléments énergétiques de la ration (glucides et lipides) telle que leur poids passe de $70 \mathrm{~g}$ à Ioo g en 6 mois ; ceci correspond à une vitesse de croissance très modeste de $0,2 \mathrm{~g} / \mathrm{jour}$, soit à peu près $4 \mathrm{p}$. Ioo de la vitesse de croissance normale. A la fin de cette période de 6 mois, un lot est sacrifié (lot IIB) et un lot est réalimenté à volonté à l'aide du régime témoin (lot IIIB). Les quatre lots restants sont maintenus, 
au moyen du même type de restriction alimentaire, au poids de roo $\mathrm{g}$ pendant 6 et i 8 mois ; à la fin de chacune de ces périodes, un lot est sacrifié (lots IIC et IID), un autre est réalimenté (lots IIIC et IIID).

TABLEAU I

Composition du régime témoin en $\mathrm{g} / \mathrm{kg}$

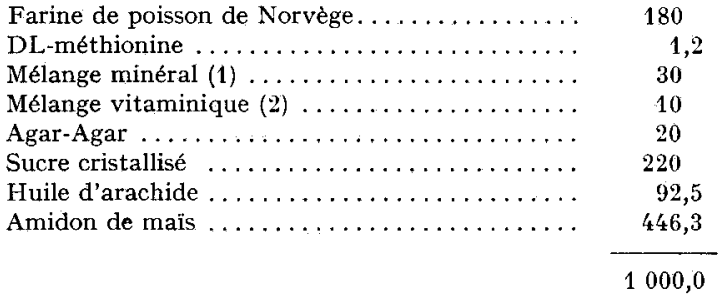

Matière sèche $(g) \ldots \ldots \ldots \ldots \ldots \ldots \ldots . .630$
(1) Composition du mélange minéral pour $30 \mathrm{~g}$.

\begin{tabular}{|c|c|}
\hline $\mathrm{CaHPO}_{4}(\mathrm{~g}) \ldots \ldots \ldots \ldots$ & 15, \\
\hline $\mathrm{CaCO}_{3}(\mathrm{~g}) \ldots \ldots \ldots \ldots \ldots$ & 6 , \\
\hline $\mathrm{NaCl}(g) \ldots \ldots \ldots \ldots \ldots$ & \\
\hline $\mathrm{KCl}(\mathrm{g}) \ldots$ & \\
\hline $\mathrm{MgCO}_{3}(\mathrm{~g}) \ldots \ldots \ldots \ldots$ & \\
\hline $\mathrm{CuSO}_{4}(\mathrm{mg}) \ldots \ldots \ldots \ldots$ & 40 \\
\hline $\mathrm{FeSO}_{4}$ (mg) $\ldots \ldots \ldots \ldots$ & 300 \\
\hline $\mathrm{ZnCO}_{3}(\mathrm{mg})+\ldots \ldots \ldots \ldots$ & 60 \\
\hline $\mathrm{NaF}$ (mg) $\ldots \ldots \ldots \ldots$ & 10 \\
\hline $\mathrm{MnSO}_{4}(\mathrm{mg}) \ldots \ldots$ & . \\
\hline $\mathrm{KI}(\mathrm{mg}) \ldots \ldots \ldots$ & \\
\hline $\mathrm{CoCO}_{3}(\mathrm{mg}) \ldots$. & \\
\hline
\end{tabular}

(2) Composition du mélange vitaminique pour $10 \mathrm{~g}$.

Thiamine (mg) $\ldots \ldots \ldots \ldots \ldots \ldots \ldots$

Acide nicotinique $(\mathrm{mg}) \ldots \ldots \ldots \ldots \ldots \quad 30$

Pyridoxine $(\mathrm{mg}) \ldots \ldots \ldots \ldots \ldots \ldots \ldots . \ldots \ldots$

Riboflavine $(\mathrm{mg}) \quad \ldots \ldots \ldots \ldots \ldots \ldots \ldots$

Panthoténate de $\mathrm{Ca}$ (mg) .......... $\quad 30$

Inositol (mg) .............. 500

Acide para-aminobenzoïque $(\mathrm{mg}) \ldots . . . \quad 500$

Vitamine $\mathrm{E}(\mathrm{mg}) \ldots \ldots \ldots \ldots \ldots \ldots \ldots \quad 100$

Vitamine $K$ (mg) ............. 5

Acide folique $(\mathrm{mg}) \ldots \ldots \ldots \ldots \ldots \ldots \ldots$

Vitamine $\mathrm{B}_{12}(\mathrm{mg}) \ldots \ldots \ldots \ldots \ldots \ldots \ldots, 0,03$

Biotine (mg) .............

Chlorure de choline $(\mathrm{mg}) \quad \ldots \ldots \ldots \ldots . \quad 1000$

Vitamine A (UI) $\ldots \ldots \ldots \ldots \ldots \ldots \ldots .10000$

Vitamine D (UI) $\ldots \ldots \ldots \ldots \ldots \ldots \ldots \ldots, \quad 2000$

Acide ascorbique $(\mathrm{mg}) \ldots \ldots \ldots \ldots . . \ldots$

Glucose ...................

En totalisant la période de croissance très ralentie et la période de maintien à poids constant, les lots IIB et IIIB, IIC et IIIC, IID et IIID sont soumis à une restriction énergétique dont la durée s'étend respectivement sur 6 mois, un an et deux ans.

Comme le lot IIIA, le lot IIIB est sacrifié au poids de $600 \mathrm{~g}$; les lots IIIC et IIID sont sacrifiés lorsqu'ils atteignent leur poids maximal, c'est-à-dire $500 \mathrm{~g}$ et $420 \mathrm{~g}$ respectivement. Le nombre maximal d'animaux sacrifiés par lot est de Io; on choisit pour cela les ro rats dont le poids se rapproche le plus de la moyenne. Lorsque la dispersion est forte (lots IIIA et IIID) seuls sont retenus pour analyse les Rats dont le poids ne s'écarte pas de plus de ro p. Ioo de part et d'autre de la moyenne.

Des expériences préliminaires ont montré qu'il n'est pas possible, dans nos conditions expérimentales, de maintenir des rats au poids constant de $7^{\circ} \mathrm{g}$ pendant des durées excédant 6 mois sans qu'apparaisse une mortalité importante. C'est pourquoi a été adopté le passage très progressif de $70 \mathrm{~g}$ à $100 \mathrm{~g}$, suivi du maintien à poids constant; cette méthode a permis de limiter la mortalité à un taux insignifiant variant de o à io p. Ioo, pour tous les lots $\mathrm{A}, \mathrm{B}$ et $\mathrm{C}$, au taux de 20 p. 100 pour le lot IID, et de 33 p. Ioo pour le lot IIID.

- La consommation alimentaire et le poids vif des animaux nourris ou réalimentés ad libitum sont mesurés chaque jour. 
Les rats restreints reçoivent chaque jour les mêmes quantités de protéines, minéraux et vitamines que consommeraient des témoins de même poids, mais la quantité d'éléments énergétiques (amidon de maïs, saccharose et huile d'arachide) est ajustée de façon que le poids des animaux varie dans les limites fixées. La proportion entre les trois sources d'éléments énergétiques est toujours conservée.

Pratiquement, pour limiter la vitesse de croissance à $0,2 \mathrm{~g} / \mathrm{jour}$ de $70 \mathrm{~g}$ à $100 \mathrm{~g}$, la quantité d'éléments énergétiques ne doit pas dépasser $20 \mathrm{p}$. 100 de la quantité consommée par des témoins de même poids ; l'arrêt de croissance à Ioo g est obtenu en ne dépassant pas I 5 p. roo de la quantité normale. Dans ces conditions, les taux protéiques des rations distribuées aux animaux restreints s'élèvent respectivement à $33 \mathrm{p}$. I oo et $37 \mathrm{p}$. Ioo.

Les locaux d'élevage sont éclairés de $7 \mathrm{~h}$ à $19 \mathrm{~h}$ et maintenus à $22^{\circ} \mathrm{C}$. Les rats sont élevés sur sciure ou copeaux de bois dans des cages en matière plastique. Les animaux restreints doivent être manipulés sans brusquerie et bénéficier d'un environnement particulièrement calme.

\section{B. - Sacrifice des animaux et prélèvement des tissus}

Chaque animal est saigné sous anesthésie à l'éther. Le sang est recueilli dans de l'azote liquide. Puis le corps est disséqué en six fractions distinctes :

- la peau ;

- les dépôts adipeux, comprenant les dépôts sous-cutanés, périrénaux, épididymaires, mésentériques ;

- le foie ;

- les viscères, que l'on adjoint au sang;

- la musculature des membres postérieurs ;

- le reste du corps, désigné sous le nom de "carcasse " et qui comprend principalement le squelette et la musculature (moins la musculature des membres postérieurs)

Chaque fraction est pesée et refroidie dans l'azote liquide. Pour chaque lot, on rassemble les fractions de même nature; on obtient ainsi six parties qui sont ensuite traitées et analysées.

Tous les traitements et méthodes analytiques qui permettent le dosage des protéines et des acides nucléiques ont été précédemment décrits (Durand et al., Ig69a).

\section{RÉSULTATS}

\section{EXPRESSION DES RÉSULTATS}

Dans l'exposé qui suit, les animaux restreints des lots IIB, IIC et IID, dont le poids moyen est de $100 \mathrm{~g}$, sont comparés aux animaux normaux de même poids du lot IIA et aux animaux normaux de $70 \mathrm{~g}$ du lot IA.

Les animaux réalimentés sont comparés aux animaux normaux de $600 \mathrm{~g} \mathrm{du}$ lot IIIA.

Les quantités d'acides nucléiques sont exprimées par la somme, en micromoles $(\mu \mathrm{M})$, des bases puriques et pyrimidiques qu'ils renferment. On peut facilement convertir ces données soit en $\mu \mathrm{g}$ de P-RNA et P-DNA en les multipliant par 3I, soit en mg de RNA et DNA en les multipliant par 0,33 .

Les consommations alimentaires sont exprimées en $g$ de matière sèche.

$$
\text { I. - Aspect et évolution des animaux (fig. I, photo I, tabl. 2) }
$$

\section{I. Animaux restreints.}

Les rats qui croissent de $70 \mathrm{~g}$ à Ioo g en 182 jours, soit à une vitesse de croissance moyenne de $0,20 \mathrm{~g} /$ jour, conservent un aspect qui diffère peu de celui des témoins de même poids ; ils se distinguent toutefois par un allongement légèrement supérieur du 


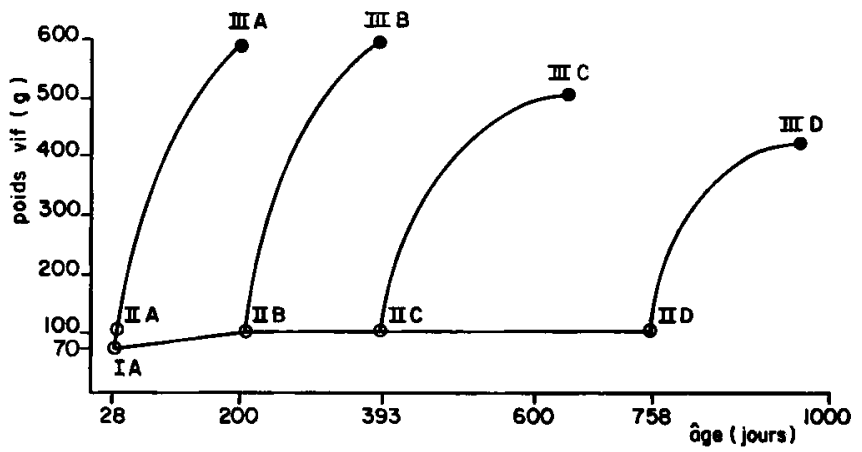

FIG. I. - Évolution du poids de rats mâles empêchés de croître pendant des durées variant de 6 mois à 2 ans par réduction de l'apport énergétique de la ration, puis réalimentés

(lots témoins : série $\mathrm{A}$; lots expérimentaux : séries $\mathrm{B}, \mathrm{C}$ et $\mathrm{D}$ )

$\circ$ : témoins de $70 \mathrm{~g}$, I00 $\mathrm{g}$ et expérimentaux empêchés de croitre;

- : témoins de $600 \mathrm{~g}$ et expérimentaux réalimentés

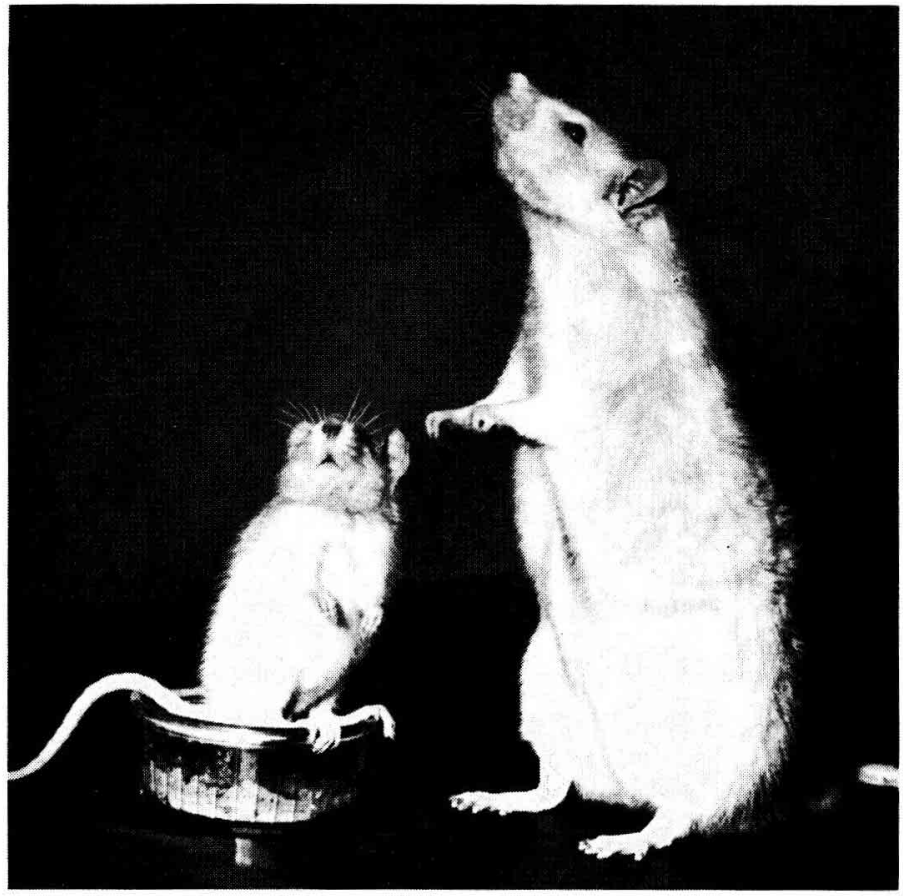

Pното 1. - Rats de même âge (7 mois) normal ou soumis à réduction de l'apport énergétique de la ration Poids respectifs : $600 \mathrm{~g}$ et Ioo $\mathrm{g}$ 
corps et de la queue : ainsi, lorsqu'ils atteignent le poids de roo g, leur longueur dépasse-t-elle de 7 p. Ioo celle des témoins du lot IIA. Par la suite, les animaux empêchés de croître au-delà de Ioo g conservent une longueur constante mais acquièrent progressivement un aspect particulier, caractérisé par un pelage long et ébouriffé, une queue effilée et noueuse; de plus, leur pénis devient saillant, comme cela a déjà été décrit chez des rats soumis à une sous-alimentation chronique et sévère (WIDDOWson et coll., I964; DURAND et PENOT, I970).

TABLEAU 2

Caractéristiques, au moment du sacrifice, de lots de Rats mâles

I) maintenus à poids constant après le sevrage par réduction de l'apport énergétique de la ration;

2) réalimentés après maintien à poids constant

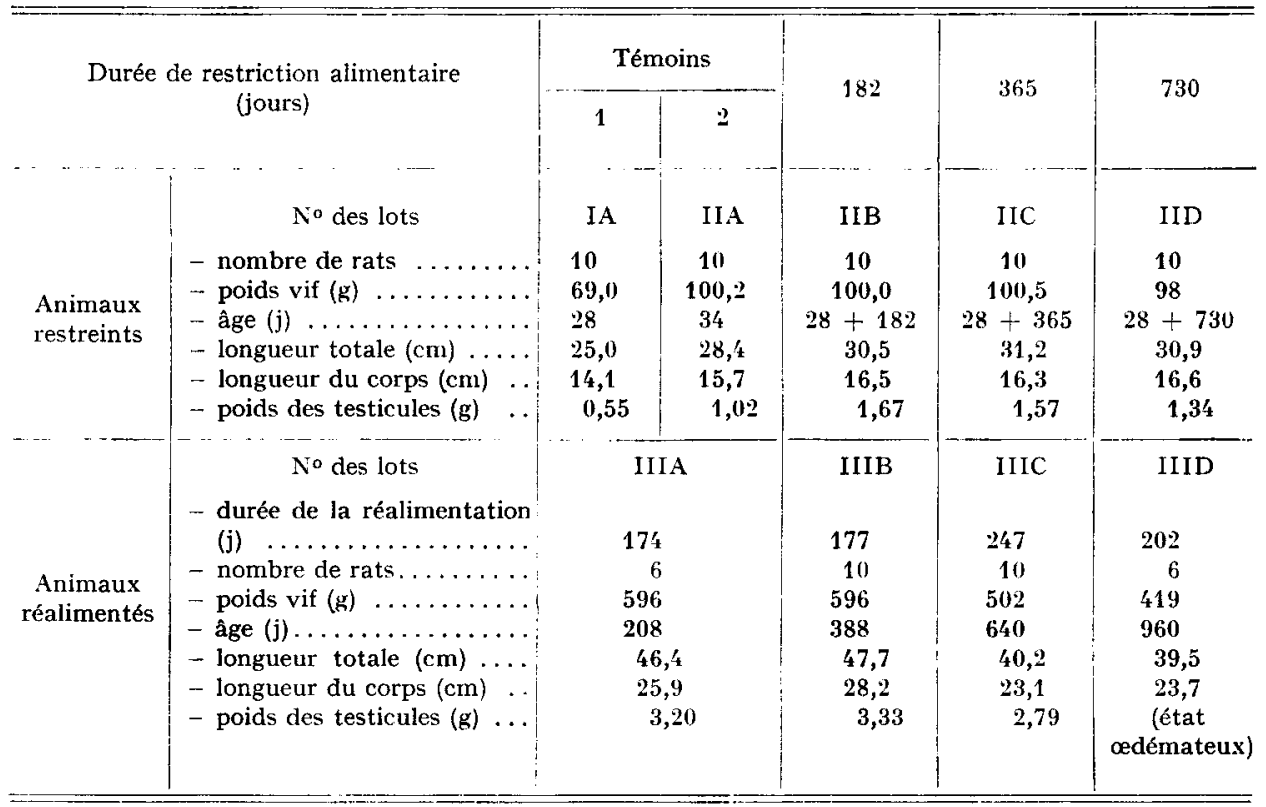

Au début de la période de restriction, la croissance des testicules est supérieure à celle de l'ensemble de l'organisme : ainsi leur poids atteint $\mathrm{I}, 67 \mathrm{~g}$ chez le lot IIB, alors qu'ils ne dépasse pas $\mathrm{I}, 02 \mathrm{~g}$ chez le lot IIA. Par la suite, lorsque la durée du maintien à poids constant se prolonge, les gonades tendent à régresser. La supériorité relative du poids des testicules dans le cas de sous-nutrition modérée ou de courte durée a déjà été signalée (SIPERSTEIN, I921 ; WIDDowson et al., I963), de même que le phénomène d'augmentation suivie de régression dans le cas de carence énergétique très forte et de longue durée (DURAND et PENOT, I970). Cependant, ce phénomène d'augmentation-régression semble d'autant moins marqué que la restriction alimentaire s'applique à des animaux d'un poids plus élevé. 
Enfin, ces animaux sous-alimentés sont d'une nervosité extrême et peuvent être sujets à des crises d'épilepsie lorsqu'un événement inhabituel vient troubler leur quiétude. Comme nous l'avons signalé dans le chapitre précédent, leur élevage exige un soin tout particulier.

\section{2. Animaux réalimentés.}

Comme cela apparaît sur la figure I et le tableau 2, il faut I74 jours au lot témoin IIIA pour passer du poids de Ioo $\mathrm{g}$ à celui de $600 \mathrm{~g}$; cela demande $\mathrm{I} 77$ jours, c'est-à-dire une durée pratiquement identique au lot IIIB, préalablement restreint pendant 6 mois ; parvenus à $600 \mathrm{~g}$, les animaux IIIB ont une longueur égale à celle des témoins et le rapport longueur du corps/longueur totale est conservé : ainsi peut-on conclure que la restriction alimentaire très sévèré, appliquée pendant 6 mois, n'a pas affecté, du moins globalement, l'aptitude des animaux à croître.

Il en va autrement lorsque les rats sont empêchés de croître au-delà du poids de Ioo $g$ pendant un ou deux ans; en effet, les rats préalablement restreints pendant un an ne dépassent pas le poids moyen de $500 \mathrm{~g}$, tandis que les rats restreints pendant deux ans plafonnent à $420 \mathrm{~g}$. De plus, les vitesses de croissance des lots IIIC et IIID sont franchement diminuées par rapport à celle des lots IIIA et IIIB. Cependant, bien que les lots IIIC et IIID atteignent un poids maximal différent, leurs dimensions longitudinales sont identiques. Ainsi déjà se dessine une similitude entre les lots témoins IIIA et IIIB d'une part, et les lots IIIC et IIID d'autre part.

La vitesse de croissance de chacun des lots, ainsi qu'éventuellement le poids maximal atteint, sont à mettre en parallèle avec l'évolution de la consommation alimentaire : alors que les témoins IIIA et les expérimentaux IIIB ingérent quotidiennement une ration de $12,5 \mathrm{~g}$ à $22 \mathrm{~g}$ lorsque leur poids passe de $100 \mathrm{~g}$ à $600 \mathrm{~g}$, la consommation quotidienne du lot IIIC augmente de II g à I $_{5} \mathrm{~g}$ lorsque le poids passe de Ioo g à $500 \mathrm{~g}$, et celle du lot IIID de I I g à I4 g seulement, lorsque le poids passe de roog à $420 \mathrm{~g}$. Ainsi, les rats soumis à une restriction énergétique très sévère peu après le sevrage pendant une durée atteignant un an ne retrouvent pas un appétit normal lorsque les conditions nutritionnelles redeviennent favorables.

Les testicules des animaux réalimentés après 6 mois de restriction sont normaux quant au poids et à l'aspect; ceux des animaux réalimentés après un an de restriction, d'un poids inférieur à la normale, sont en voie de dégénérescence, tandis que les gonades des animaux réalimentés après deux ans de restriction, complètement dégénérées, présentent un état œdémateux total; il est vrai, cependant, que les rats des lots IIIC et IIID sont sacrifiés respectivement à l'âge de $640 \mathrm{j}$ et $960 \mathrm{j}$, alors que la durée moyenne de vie de l'espèce est estimée, dans des conditions normales, à I ooo jours environ (KAYSER et coll., I966) ; il s'agit donc, chronologiquement du moins, de vieux animaux chez lesquels, en ce qui concerne l'anatomie et la physiologie des testicules, il faudrait faire la part du vieillissement et des privations alimentaires antérieures.

Les crises d'épilepsie disparaissent dès que les animaux sont réalimentés à volonté. 

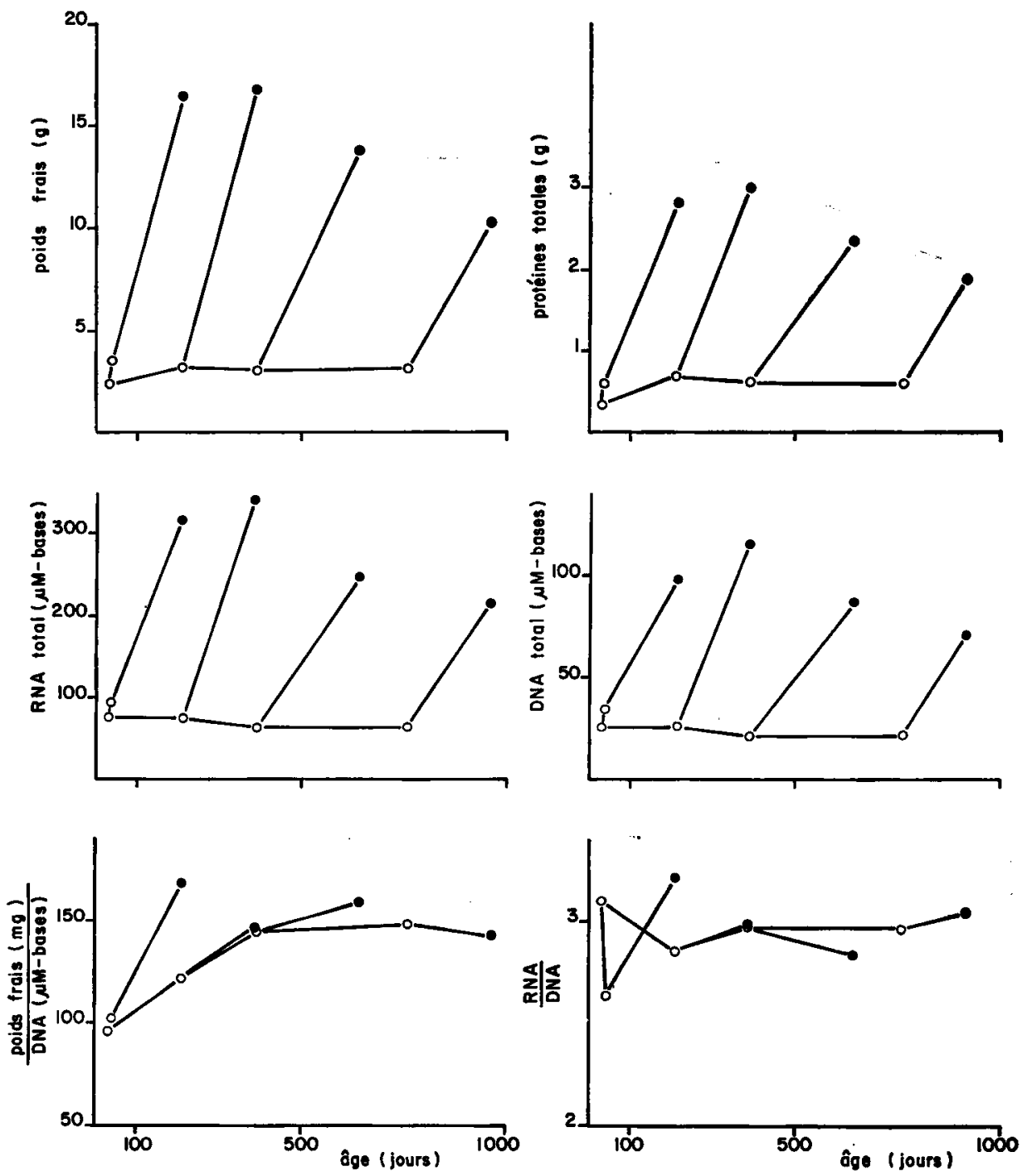

FIG. 2. - Foie

Evolution des contenus en protéines et en acides nucleiques chez le Rat male

I) empêché de croître après le sevrage par réduction de l'apport énergétique de la ration;

2) réalimenté après maintien à poids constant.

$\circ$ : témoins de $70 \mathrm{~g}$, roo $\mathrm{g}$ et expérimentaux empecchés de croître ;

- : témoins de 6oo $\mathrm{g}$ et expérimentaux réalimentés 


\section{2. - Effets de la restriction énergétique \\ et de la réalimentation sur les diverses fractions corporelles}

2. I Foie (fig. 2).

\section{II. Restriction énergétique.}

Le foie des animaux expérimentaux atteint, puis conserve, un poids intermédiaire entre celui des témoins IA et celui des témoins IIA ; il se rapproche cependant davantage du dernier, auquel il n'est inférieur que de Io $\mathrm{p}$. Ioo. Le contenu protéique de l'organe est au contraire plus élevé chez les expérimentaux que chez les témoins IIA, mais cette supériorité diminue de $\mathrm{I} 2 \mathrm{p}$. Ioo à $2 \mathrm{p}$. Ioo lorsque la durée de la restriction passe de 6 mois à 2 ans.

Les quantités d'acides nucléiques sont fortement limitées par la restriction énergétique utilisée; loin d'atteindre les quantités observées chez le lot IIA, elles demeurent soit équivalentes, soit inférieures à celles du lot IA. Ainsi, le contenu hépatique en RNA du lot IIB est du même ordre que celui du lot IA, mais ceux des lots IIC et IID lui sont inférieurs de $I 7 \mathrm{p}$. Ioo. De même, la quantité de DNA, très voisine chez les lots IA et IIB, est inférieure de I4 p. Ioo chez les lots IIC et IID comparés au lot IA.

A ces données correspondent un accroissement du rapport poids frais/DNA des lots expérimentaux; cet accroissement atteint environ $22 \mathrm{p}$. Ioo pour le lot IIB et $47 \mathrm{p}$. Ioo pour les lots IIC et IID comparés aux lots IIA et IA, qui sont très proches l'un de l'autre en la matière. Le recul du RNA étant un peu plus marqué que celui du DNA, le rapport RNA/DNA se trouve légèrement diminué chez les expérimentaux.

\section{12. Réalimentation.}

Ia réalimentation ramène le poids du foie des animaux IIIB à une valeur normale. Les foies des animaux IIIC et IIID ne récupèrent pas totalement de la carence énergétique préalable, et restent d'un poids inférieur à celui que l'on note chez les témoins IIIA ; toutefois le rapport poids du foie/poids du corps est respecté. Le contenu protéique représente dans tous les cas environ $20 \mathrm{p}$. roo du poids frais; il est donc diminué dans le cas des lots IIIC et IIID dans la même mesure que le poids frais.

Les contenus en RNA et DNA, et particulièrement en ce dernier, sont sensiblement plus élevés dans le foie des animaux IIIB que dans celui des témoins IIIA, soit respectivement de $8 \mathrm{p}$. Ioo pour le RNA et I7 p. Ioo pour le DNA. Par contre, ces contenus se trouvent amoindris chez les lots IIIC et IIID, respectivement de 2I p. Ioo et 3I,5 p. Ioo pour le RNA, et de Io,4 p. Ioo et $27 \mathrm{p}$. Ioo pour le DNA.

Pour chacun des cas considérés, les variations du poids frais et des contenus en acides nucléiques allant dans le même sens, les rapports poids frais/DNA et RNA/DNA sont assez peu modifiés.

\section{2. Muscles des membres postérieurs (fig. 3).}

\section{2I. Restriction énergétique.}

Les muscles des membres postérieurs des animaux restreints ont, dans tous les cas, un poids supérieur à celui des témoins IIA, même si cette supériorité, qui atteint I2 p. Ioo pour les lots IIB et IIC, ne dépasse pas 2,7 p. Ioo pour le lot IID. 
De même, les contenus protéiques de l'ensemble musculaire étudié sont plus élevés chez les rats expérimentaux que chez les témoins du lot IIA, l'avantage étant du même ordre, soit environ 2 I p. Ioo, pour les lots IIB et IIC, mais ne dépassant pas 9 p. Ioo pour le lot IID.
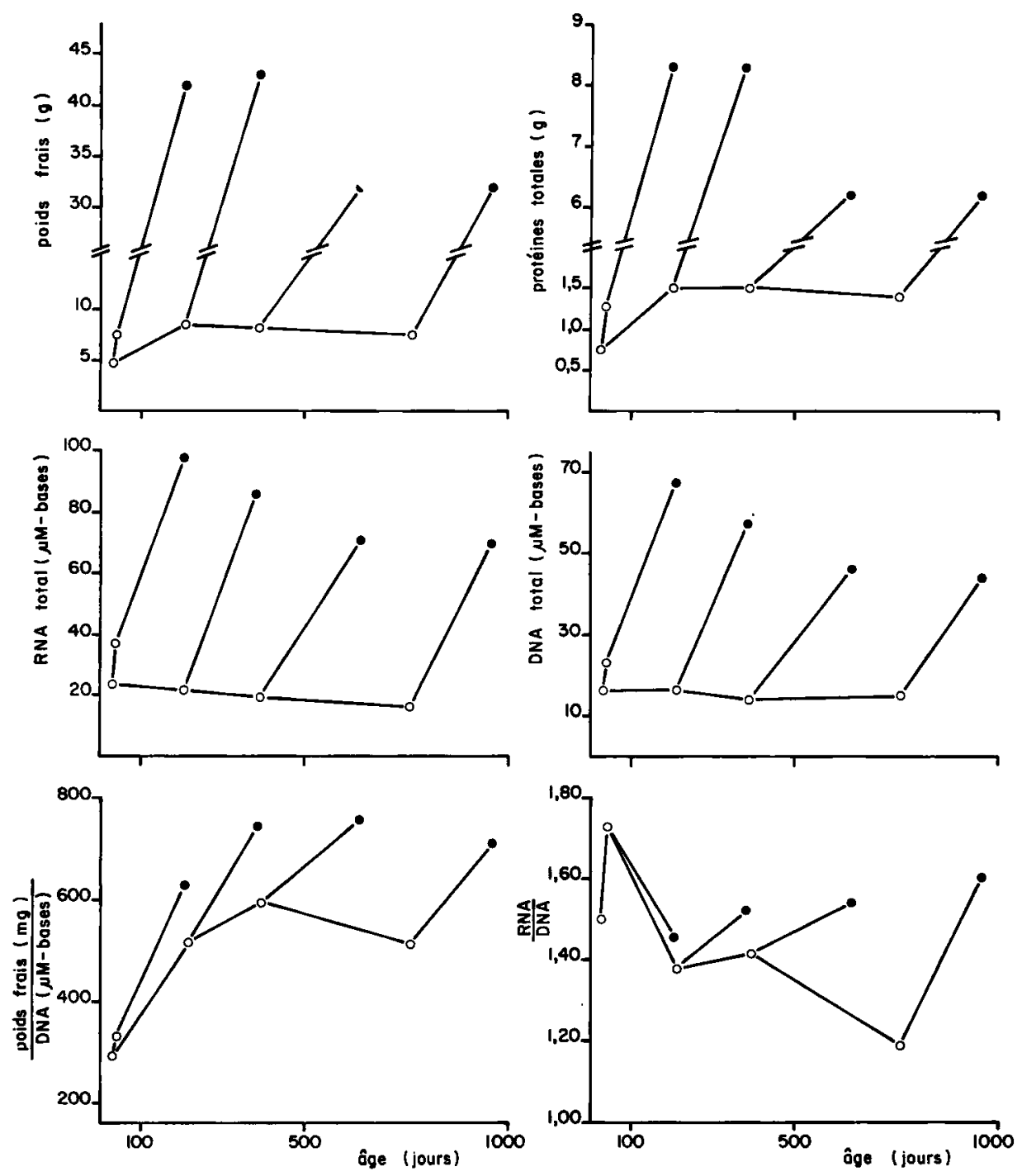

Fig. 3. - Muscle des membres postérieurs

Evolution des contenus en protéines et en acides nucléiques chez le Rat mâle

I) empêché de crôitre après le sevrage par réduction de l'apport énergétique de la ration;

2) réalimenté après maintien à poids constant.

0 : témoins de $70 \mathrm{~g}, 100 \mathrm{~g}$ et expérimentaux empêchés de croître ;

- : témoins de $600 \mathrm{~g}$ et expérimentaux réalimentés 
Comme le foie, les muscles des restreints contiennent moins de RNA que ceux des témoins IIA, mais en contiennent également moins que ceux des témoins IA. Le désavantage par rapport à ces derniers, qui varie de 5,4 p. Ioo à $22 \mathrm{p}$. 100, est d'autant plus marqué que la durée de maintien à poids constant est plus longue. Les quantités de DNA renfermées dans la musculature des expérimentaux sont également très inférieures à celles que 1'on note chez les témoins IIA et sont équivalentes ou légèrement inférieures à celles que l'on observe chez les témoins IA.

Ainsi, chez les restreints, la croissance musculaire peut se poursuivre sans qu'augmentent les quantités de DNA.

Il en résulte que les muscles des lots restreints sont caractérisés par un rapport poids frais/DNA particulièrement élevé, supérieur de 56 p. Ioo à celui qu'on observe chez le lot témoin IIA. A l'inverse, le DNA restant relativement stable et le RNA régressant sensiblement, le rapport $\mathrm{RNA} / \mathrm{DNA}$ se trouve amoindri chez les lots expérimentaux.

\section{22. Réalimentation.}

En ce qui concerne le poids frais et le contenu protéique, la récupération est complète chez le lot IIIB, mais elle ne l'est pas pour les lots IIIC et IIID, qui accusent un désavantage de 24 p. Ioo; il faut cependant noter que ces deux derniers lots sont tout à fait comparables à cet égard. En matière d'acides nucléiques, la récupération n'est jamais complète, même pour le lot IIIB, désavantagé de II p. IOO pour le RNA et de $15 \mathrm{p}$. roo pour le DNA par rapport aux témoins IIIA. Cette déficience en acides nucléiques est plus marquée encore dans la musculature des lots IIIC et IIID puisqu'elle atteint $28 \mathrm{p}$. Ioo et $33 \mathrm{p}$. Ioo pour le RNA et le DNA respectivement; il faut remarquer l'analogie qui rapproche les lots IIIC et IIID.

Le rapport poids frais/DNA, qui était beaucoup plus élevé chez les animaux empêchés de croître que chez les témoins correspondants, conserve cette supériorité chez les trois lots expérimentaux réalimentés par rapport au lot témoin IIIA. Le rapport RNA/DNA, par contre, amoindri au cours de la période de sous-alimentation, redevient parfaitement normal chez les trois lots.

\section{3. Peau (fig. 4).}

\section{3I. Restriction énergétique.}

Le poids de la peau des rats maintenus au poids de roo g est inférieur à celui des témoins de même poids. Pour les animaux restreints pendant 6 mois et un an, cette infériorité est de $22 \mathrm{p}$. Ioo, mais elle atteint $33 \mathrm{p}$. Ioo chez les animaux restreints pendant 2 ans. Cependant, la concentration en protéines de la peau des expérimentaux étant fortement accrue, le contenu protéique de cette fraction dépasse celle des témoins de $8 \mathrm{p}$. Ioo après 6 mois de restriction, de $2 \mathrm{p}$. IOO après I an ; i1 est toutefois inférieur de 7 p. Ioo chez les rats empêchés de croître pendant 2 ans.

Pour ce qui est des acides nucléiques, la sous-alimentation énergétique provoque des effets comparables à ceux qui sont observés dans le foie et les muscles. Chez les trois lots expérimentaux, les contenus en RNA sont nettement moins élevés que ceux que l'on relève chez les témoins de $70 \mathrm{~g}$; mais tandis que les lots IIB et IIC présentent une infériorité identique et modérée de ro $\mathrm{p}$. Ioo, le lot IID accuse une chute de 29 p. Ioo. 
Le DNA est, une fois encore, moins touché que le RNA par la restriction ; la peau des animaux des lots IIB et IIC n'en contient pas notablement moins que celle du lot IA; toutefois, comme pour l'ensemble des caractéristiques étudiées, le lot IID, désavantagé de I8 p. Ioo par rapport au lot IA, se démarque nettement.
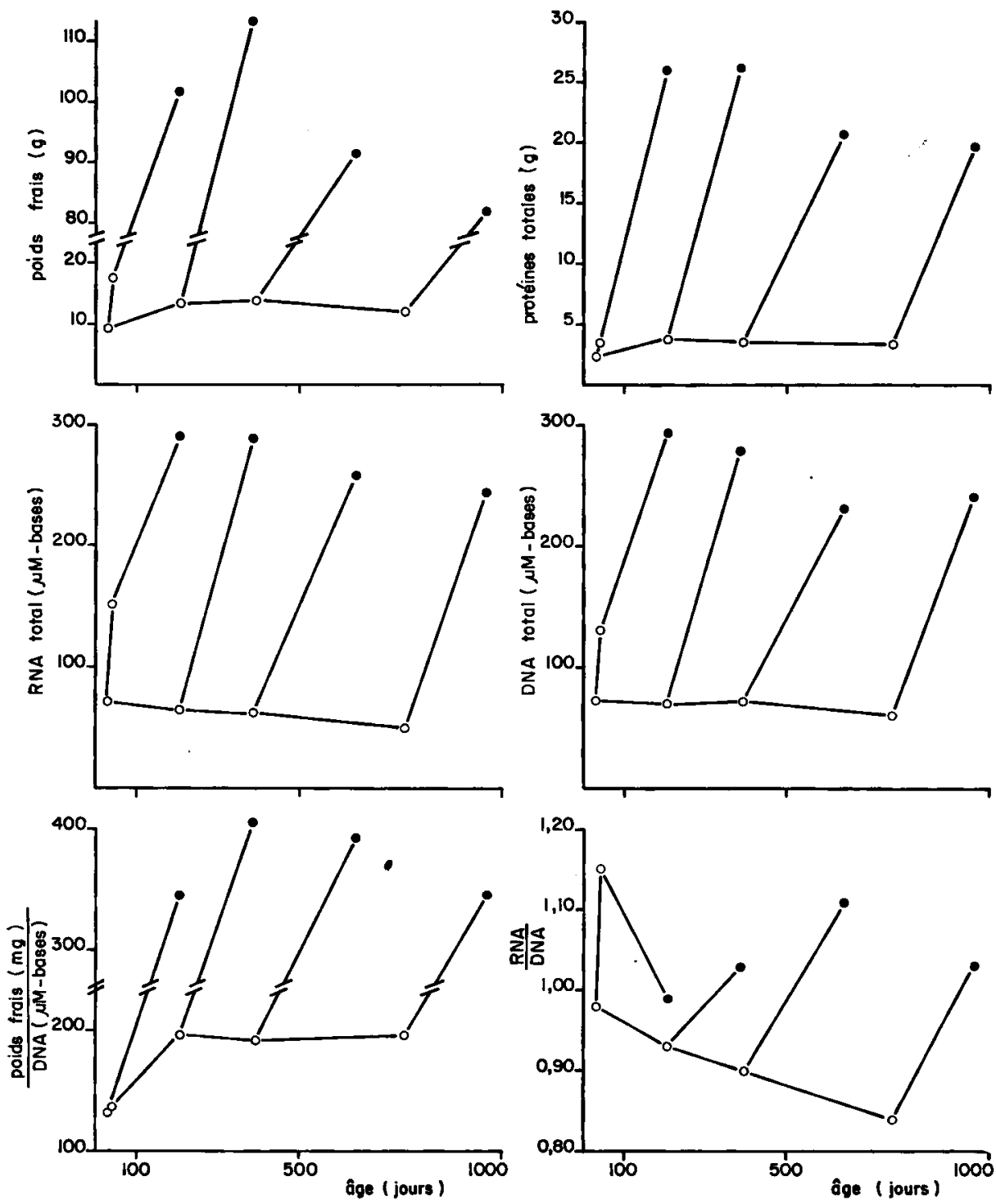

FIg. 4. - Peau

Evolution des contenus en protéines et en acides nucleiques chez le Rat mâle

I) empêché de croître après le sevrage par réduction de l'apport énergétique de la ration;

2) réalimenté après maintien à poids constant.

o : témoins de $70 \mathrm{~g}$, Ioo $\mathrm{g}$ et expérimentaux empêchés de croître;

- : témoins de $600 \mathrm{~g}$ et expérimentaux réalimentés 

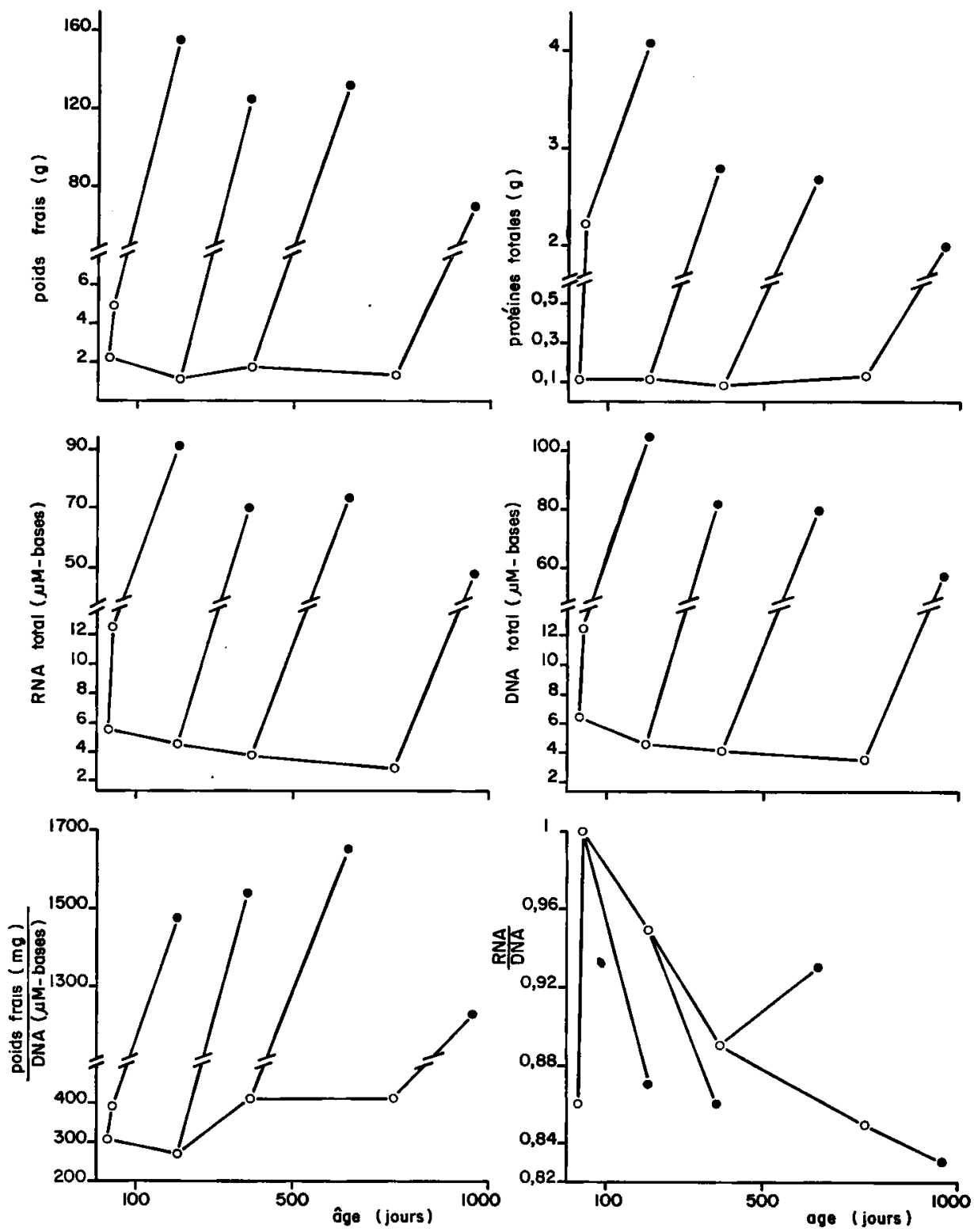

Fig. 5. - Tissus adipeux

Erolution des contenus en protéines et en acides nucléiques chéz le Rat male

I) empêché de croître après le sevrage par réduction de l'apport énergétique de la ration;

2) réalimenté après maintien à poids constant.

o: témoins de $70 \mathrm{~g}$, Ioo $\mathrm{g}$ et expérimentaux empêchés de croître;

- : témoins de $600 \mathrm{~g}$ et expérimentaux réalimentés 
Par ailleurs, les rapports poids frais/DNA, relatifs aux lots expérimentaux, sont remarquablement homogènes et supérieurs de $45 \mathrm{p}$. Ioo environ à celui des témoins des lots IA et IIA. En revanche, et cela résulte de la relative stabilité du DNA, les rapports RNA/DNA sont amoindris chez les expérimentaux, surtout chez le lot IID.

\section{32. Réalimentation.}

En poids frais, la récupération est complète pour le lot IIIB, mais incomplète pour les lots IIIC et IIID qui se situent respectivement à Io p. Ioo et $20 \mathrm{p}$. Ioo au-dessous des témoins.

Chez le lot IIIB, la récupération est complète pour l'ensemble des autres caractéristiques étudiées : protéines, RNA et DNA. Pour les lots IIIC et IIID, les contenus protéique, ribonucléique et désoxyribonucléique restent inférieurs à ceux des témoins, mais on ne relève pas de différence notable entre les deux lots : les écarts avec le lot témoin IIIA sont de $24 \mathrm{p}$. Ioo pour le contenu protéique, et respectivement de $\mathrm{I} 4 \mathrm{p}$. Ioo et $20 \mathrm{p}$. Ioo pour les contenus en RNA et DNA. Les rapports poids frais/DNA et RNA/DNA redeviennent, dans les trois cas, très proches de la normale.

\section{4. Tissus adipeux (fig. 5).}

\section{41. Restriction énergétique.}

Chez les trois lots restreints, le poids de l'ensemble des dépôts adipeux est inférieur en moyenne de $70 \mathrm{p}$. Ioo à celui que l'on note chez les témoins IIA et il est même nettement inférieur à celui des animaux du lot IA.

Par contre, les contenus protéiques de ces tissus, au demeurant peu différents entre lots expérimentaux, sont pratiquement équivalents à celui du lot IA.

Les contenus en RNA et DNA sont toujours moins élevés chez les expérimentaux que chez les témoins IA, et sont d'autant plus faibles que la durée de restriction est plus longue. Ainsi, le lot IIID, empêché de croître pendant deux ans, a perdu environ 47 p. Ioo du RNA et 46 p. Ioo du DNA qu'il contenait à $70 \mathrm{~g}$.

Les rapports RNA/DNA restent presque inchangés par rapport au lot témoin IA. Cependant, le rapport poids frais/DNA est voisin de celui que l'on observe chez les témoins IIA.

\section{42. Réalimentation.}

Aucun des lots préalablement restreints ne retrouve une masse de tissus adipeux aussi importante que celle des témoins. Chez les lots IIIB et IIIC, l'ensemble des dépôts adipeux représente 80 à 85 p. Ioo de celui des témoins mais n'en est pas significativement différent; la difficulté de récupération est surtout sensible chez le lot IIID, préalablement maintenu deux ans à poids constant, chez lequel la quantité de tissus adipeux ne représente que $45 \mathrm{p}$. Ioo de celle que l'on relève chez le lot témoin IIIA. Chez les trois lots expérimentaux, le contenu protéique des tissus adipeux sont amoindris à peu près dans les mêmes proportions que le poids frais.

Pour les acides nucléiques, le rattrapage est assez satisfaisant chez les lots IIIB et IIIC, puisque les quantités de RNA et DNA que renferment leurs tissus adipeux représentent 80 p. Ioo de la normale. Cependant le lot IIID apparaît, là encore, 

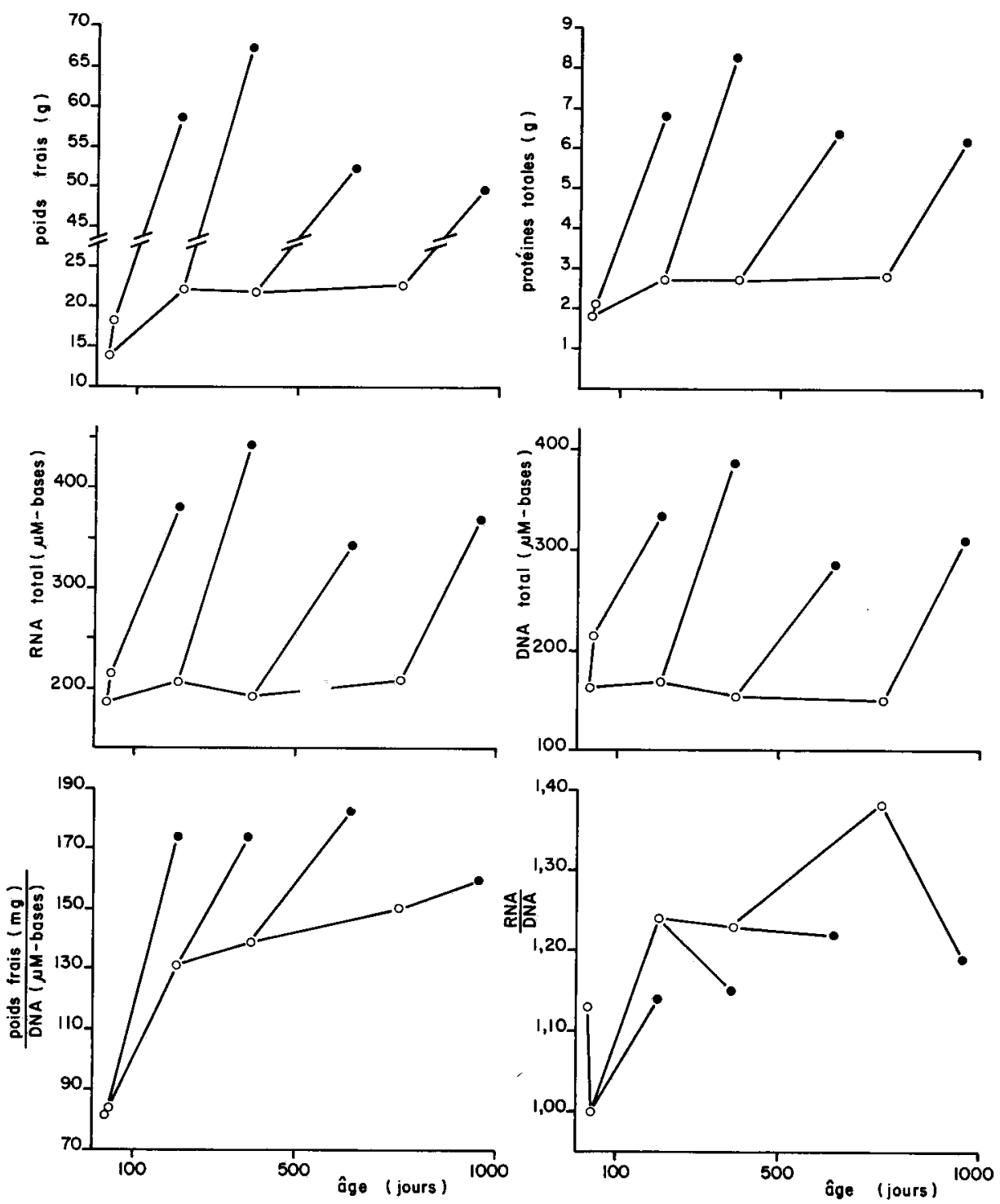

FIG. 6. - Viscères + Sang

Évolution des contenus en protéines et en acides nucléiques chez le Rat mâle

I) empêché de crô̂tre après le sevrage par réduction de l'apport énergétique de la ration;

2) réalimenté après maintien à poids constant.

0 : témoins de $70 \mathrm{~g}$, Ioo $\mathrm{g}$ et expérimentaux empêchés de crôtre ;

- : témoins de $600 \mathrm{~g}$ et expérimentaux réalimentés 
très désavantagé puisque chez lui les quantités de RNA et de DNA ne dépassent pas $48 \mathrm{p}$. Ioo et $53 \mathrm{p}$. Ioo de la normale.

Les rapports RNA/DNA sont du même ordre dans tous les cas, tandis que le rapport poids frais/DNA est accru chez les lots IIIB et IIIC, mais diminué chez le lot IIID.

\section{5. Viscères + Sang (fig. 6).}

\section{5I. Restriction alimentaire.}

De même que celui de la musculature des membres postérieurs, le poids frais de cet ensemble hétérogène que constituent les viscères et le sang est équivalent chez les trois lots expérimentaux et supérieur de $20 \mathrm{p}$. roo à celui des témoins IIA.

Le contenu protéique de cet ensemble est également plus élevé, soit 30 p. I00, chez les expérimentaux que chez les témoins de même poids.

Le contenu en RNA est du même ordre chez les trois lots expérimentaux et intermédiaire entre celui des lots IIA et IA.

Le contenu en DNA est globalement au même niveau chez les expérimentaux et les témoins IA ; il ne manifeste qu'une légère tendance à diminuer avec la durée de restriction.

Il apparaît par ailleurs que le rapport poids frais/DNA est :

I. équivalent chez le témoin IA et IIA,

2. plus élevé chez les expérimentaux, et d'autant plus élevé que la durée de restriction est plus longue, la supériorité des expérimentaux variant de $57 \mathrm{p}$. Ioo à $79 \mathrm{p}$. IOO.

Le rapport RNA/DNA l'emporte également chez les animaux restreints, mais les écarts avec les témoins IIA, qui n'excèdent pas 38 p. Ioo, sont moins marqués.

\section{52. Réalimentation.}

Aussi bien pour le poids frais que pour le contenu protéique, le lot IIB dépasse nettement le lot témoin IIIA, soit respectivement de I7 p. IOo et 2I p. IOO, alors que les lots IIIC et IIID sont au contraire désavantagés; ces deux derniers lots sont, par ailleurs, très comparables entre eux.

On constate des phénomènes analogues en ce qui concerne les acides nucléiques : tant pour les contenus en RNA qu'en DNA, le lot IIIB est supérieur au lot IIIA, soit I6 p. Ioo et I5 p. Ioo respectivement, alors que les lots IIIC et IIID se situent légèrement au-dessous.

Pour les rapports poids frais/DNA et RNA/DNA, on observe des écarts peu importants entre les quatre lots.

\section{6. Carcasse (fig. 7).}

\section{6r. Restriction alimentaire.}

Dans cet ensemble, constitué essentiellement de la musculature (moins celle des membres postérieurs) et du squelette, on observe des résultats comparables à ceux qui concernent la musculature. Les poids frais et les contenus protéiques, équivalents chez les trois lots expérimentaux, sont plus élevés, de $9 \mathrm{p}$. Ioo, que chez le lot témoin de même poids IIA. Leș quantités d'acides nucléiques par contre, 

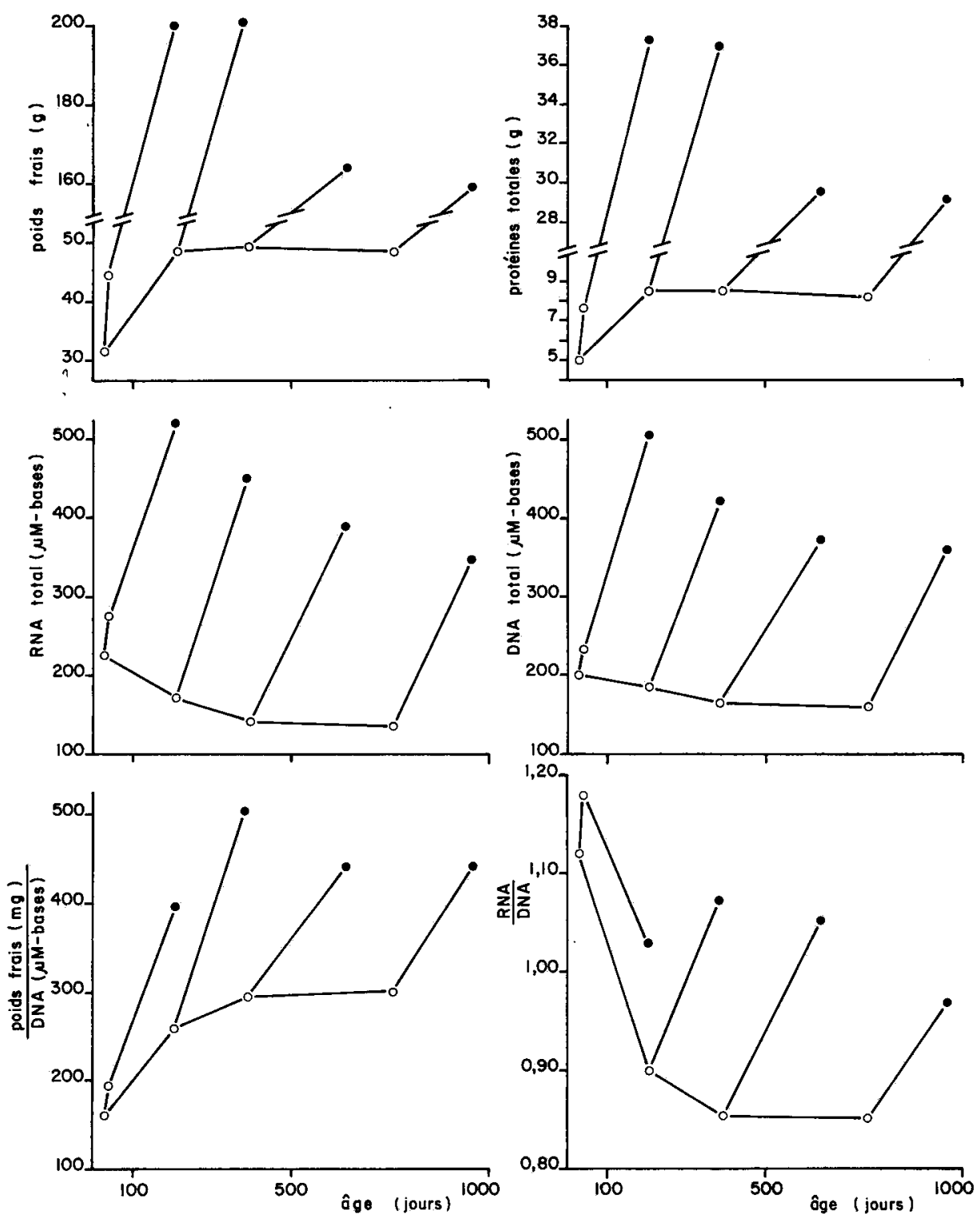

Fig. 7. - Carcasse

Évolution des contenus en protéines et en acides nucléiques chez le Rat mâle

I) empêché de croître après le sevrage par réduction de l'apport énergétique de la ration;

2) réalimenté après maintien à poids constant.

$\circ$ : témoins de $70 \mathrm{~g}$, roo g et expérimentaux empêchés de croître ;

- : témoins de $600 \mathrm{~g}$ et expérimentaux réalimentés 
loin d'atteindre celles de ce dernier, sont inférieures aux quantités observées chez le lot IA. Ainsi, pour le lot le plus défavorisé IID, less quantités de RNA et de DNA sont respectivement inférieures de $40 \mathrm{p}$. Ioo à $20 \mathrm{p}$. Ioo à celles du lot IA.

Le rapport poids frais/DNA se trouve, dès lors, fortement accru par la sousalimentation énergétique : de $63 \mathrm{p}$. Ioo pour le lot IIB à $87 \mathrm{p}$. Ioo pour le lot IID.

Par contre, le RNA étant plus touché par la carence que le DNA, le rapport RNA/DNA accuse une notable diminution chez les lots expérimentaux.

\section{62. Réalimentation.}

La teneur en protéines est équivalente chez tous les lots de la série III. Les contenus protéiques varient donc comme les poids frais. A cet égard, la récupération du lot IIIB est complète. Il n'en va pas de même des lots IIIC et IIID qui sont désavantagés de $20 \mathrm{p}$. Ioo. Cependant, l'élément le plus remarquable est certainement l'équivalence des carcasses de ces deux lots.

Les quantités d'acides nucléiques sont toujours plus faibles chez les lots expérimentaux que chez le lot témoin ; l'infériorité s'aggrave avec la durée de la restriction et évolue de même pour le RNA et le DNA. Ainsi, chez les expérimentaux, le rapport poids frais/DNA est-il accru, tandis que le rapport RNA/DNA est conservé à une valeur voisine de $\mathrm{I}$.

\section{DISCUSSION}

Le présent travail concerne l'évolution des principaux tissus et organes de rats mâles soumis à une restriction très sévère des seuls éléments énergétiques de la ration ; elle concerne également la capacité de reprise de croissance de ces différents tissus et organes, lorsque les animaux peuvent de nouveau consommer librement un régime équilibré.

\section{I. - Effets de la restriction énergétique}

La restriction est appliquée à partir du poids de $70 \mathrm{~g}$, c'est-à-dire une semaine après le sevrage, et s'étend sur des périodes dont la durée varie de 6 mois à deux ans. Au cours des six premiers mois, on permet aux animaux de passer très progressivement du poids de $70 \mathrm{~g}$ à celui de Ioo $\mathrm{g}$, puis, pour des durées de sous-nutrition plus longues, on les maintient au poids de roo $\mathrm{g}$; des expériences préalables ont montré, dans les conditions expérimentales utilisées, qu'il n'est pas possible de maintenir des rats à un poids inférieur pendant plus d'un an sans que se manifeste une mortalité importante, incompatible avec une expérimentation convenable; il apparaît ainsi que la probabilité de survie à une carence énergétique très sévère durant la croissance est d'autant plus réduite que le stade de développement de l'animal est plus précoce. Pour la souche de rats utilisée, le poids de Ioo g correspond à celui d'un animal âgé de 5 semaines, alors que la puberté est acquise à $250 \mathrm{~g}$, à l'âge de 8 semaines environ.

La durée moyenne de vie du rat qui reçoit sa vie durant un régime semi-synthétique équilibré suivant les normes en vigueur est approximativement de I ooo jours (KAYSER et al., I966) ; ainsi, certains de nos animaux (lots IID et IIID) sont-ils empêchés de croître jusqu'à un âge qui représente 75 p. Ioo de l'espérance de vie 
de l'espèce. A notre connaissance, seuls McCAY et al., 1935 ont imposé à des rats une sous-nutrition énergétique pendant aussi longtemps; encore ces auteurs appliquaient-ils une restriction moins sévère, puisqu'ils permettaient à leurs animaux une croissance de Io $\mathrm{g}$ à intervalles de 2 ou 3 mois.

\section{I. Poids des tissus et organes.}

Si l'on compare à des témoins de même poids des rats mâles dont la vitesse de croissance est limitée aux deux tiers de la normale par restriction de l'apport calorique de la ration (DURAND, I973), on observe chez les expérimentaux une augmentation relative du poids des muscles et des viscères, une diminution relative du poids du foie et des tissus adipeux, tandis qu'à ce point de vue la peau et la carcasse restent inchangées; la stabilité de la carcasse peut s'expliquer soit par une sensibilité particulière de la musculature des membres postérieurs à la carence énergétique, soit, et cela est plus probable, par le rôle modérateur du squelette.

Lorsque la restriction est assez sévère pour ralentir à l'extrême ou annuler la vitesse de croissance, comme c'est le cas dans le présent travail, on constate une augmentation relative du poids des muscles MP, des viscères et de la carcasse, en même temps qu'une diminution relative du poids du foie, de la peau et des tissus adipeux. Ces conclusions confirment celles d'un précédent travail (DuRAND et Penot, I970) dans lequel des rats sont maintenus au poids de $68 \mathrm{~g}$ pendant des durées variant de 50 à Ioo jours.

Ainsi donc, une carence énergétique modérée tend à favoriser la musculature et les viscères (moins le foie), à désavantager le foie et les tissus adipeux, tandis que peau et carcasse restent inchangées ; mais si la carence vient à être aggravée, la carcasse rejoint le groupe des fractions favorisées, et la peau celui des fractions défavorisées. Cette dernière apparaît ainsi comme l'ultime source de réserves, après que les dépôts adipeux aient pratiquement épuisé les leurs.

Les résultats présentés ici indiquent que l'équilibre massique établi après 6 mois de carence entre les six fractions corporelles considérées est conservé aussi longtemps que se prolonge cette dernière. Il ressort d'ailleurs de données précédentes (DURAND et PENOT, I970) que cet équilibre est déjà atteint après 50 jours chez des rats maintenus au poids de $68 \mathrm{~g}$.

I1 se révèle donc que, face aux conditions nutritionnelles imposées, une répartition nouvelle des principales masses corporelles s'instaure très rapidement ; il n'est pas exclus toutefois, et les testicules en sont l'exemple, que certains organes trouvent plus lentement leur équilibre ou manifestent une évolution pondérale continue.

\section{2. Contenus protéiques.}

Il ressort de travaux précédents (Durand et al., ig67; Durand et Penot, I970; DURAND, I973) que la réduction de l'apport énergétique de la ration distribuée à des animaux sevrés favorise l'accumulation de protéines dans les diverses fractions corporelles, sauf, sous certaines conditions, dans le foie, et, d'une façon générale, dans les tissus adipeux.

Ces conclusions sont confirmées par les résultats de ce travail qui montrent que l'arrêt de croissance s'accompagne d'un enrichissement du contenu protéique dans cinq des six fractions étudiées. 
Parmi les fractions dont le contenu protéique se trouve accru, l'ensemble viscères + sang, avec une supériorité durable de $30 \mathrm{p}$. roo par rapport à l'ensemble correspondant d'animaux témoins de même poids, est le plus avantagé ; viennent ensuite les muscles et la carcasse, qui présentent une supériorité de $20 \mathrm{p}$. Ioo environ; toutefois, l'excédent protéique de ces deux fractions décroît lorsque la durée de la carence dépasse un an ; ainsi peut-on penser que la musculature résiste bien pendant un an à l'interruption de croissance, mais supporte difficilement plus longtemps une carence énergétique aussi rigoureuse.

En ce qui concerne le foie, l'avantage sur les témoins de même poids, qui atteint I 2 p. Ioo après 6 mois de restriction, se perd progressivement lorsque la durée de celle-ci se prolonge, pour devenir négligeable après deux ans.

Le contenu protéique de la peau des animaux carencés dépasse celui des témoins de même poids après 6 mois de restriction, mais, comme dans le cas du foie, cet avantage se perd rapidement : il devient négligeable après un an et se transforme en déficit pour des durées plus longues. Enfin, les tissus adipeux des animaux expérimentaux sont les seuls à contenir systématiquement et considérablement moins de protéines que ceux des témoins de même poids.

Si l'on établit un bilan pour l'organisme entier (tabl. 3), on constate que les animaux des trois lots restreints IIB, IIC, IID renferment plus de protéines que les animaux du lot témoin IIA; les lots carencés pendant 6 mois et un an sont équivalents et l'emportent de I6 p. roo sur les témoins, tandis que la supériorité du lot carencé pendant deux ans n'excèdent pas $\mathrm{i} 2 \mathrm{p}$. Ioo.

\section{3. Contenus en acides nucléiques: blocage de la multiplication cellulaire.}

En ce qui concerne les acides nucléiques, nous ne comparerons pas les animaux expérimentaux aux témoins de même poids du lot IIA, dont les diverses fractions corporelles contiennent beaucoup plus de DNA et RNA. Compte tenu des résultats, il semble plus rationnel de comparer les animaux restreints aux témoins du lot IA, dont le poids correspond à celui du début de l'application de la restriction énergétique.

Il apparaît en effet, dans la grande majorité des cas, que les divers tissus et organes des animaux expérimentaux contiennent des quantités d'acides nucléiques égales ou inférieures à celles que contiennent les tissus et organes correspondants des témoins IA.

Chez les rats du lot IIB, conduits en 6 mois de $70 \mathrm{~g}$ à Ioo $\mathrm{g}$, on ne relève ni gain, ni perte appréciable de RNA et DNA dans le foie et les muscles. On relève par contre des diminutions considérables de l'un et l'autre acides nucléiques dans les tissus adipeux, et des diminutions notables dans la carcasse et la peau. La carcasse étant composée essentiellement du squelette et de la musculature, et les muscles n'étant pas en cause, on peut penser que la perte constatée est due au squelette et plus spécialement à la moelle osseuse ; ceci est à rapprocher des travaux de STEKEI, et Sмiтr (1969a et $b$ ), relatifs à l'hématopoièse chez le porcelet soumis à restriction de l'apport énergétique. Quant à la peau, on sait qu'elle n'est pas particulièrement touchée par une carence modérée (DuRAND, I973), mais qu'elle est par contre sensible aux restrictions énergétiques très rigoureuses (DURAND et al., I969 $b$; DURAND et PENOT, I97o).

Les viscères enfin conservent, comme le foie et les muscles, leur capital en DNA, mais marquent leur caractère particulier en augmentant leur capital en RNA. L'enri- 
chissement des viscères en RNA, dans le cas de malnutrition calorique, a déjà été rapporté (DURAND, I972) et peut être rapproché de la stimulation concomitante de la synthèse protéique observée par ARNAL et coll. (I972).

Par ailleurs, plusieurs auteurs (DuRANd et al., I967; ElLiot et CheEk, 1968 ; Graystone et ChEEk, I969; Hill et al., I970 ; DURAND, 1973) ont montré qu'à poids égal d'animal, les tissus et organes des animaux dont la vitesse de croissance est ralentie par restriction énergétique comptent moins de cellules que ceux des animaux à croissance normale. Les résultats du présent travail confirment ces données et, de plus, montrent qu'il est possible de conduire des rats du poids de $70 \mathrm{~g}$ à celui de Ioo $\mathrm{g}$, soit une croissance de $42,8 \mathrm{p}$. Ioo, sans augmentation du contenu corporel en DNA, alors que normalement la quantité de ce dernier passe de $483 \mu \mathrm{M}$ à $648 \mu \mathrm{M}$, soit une augmentation de $34 \mathrm{p}$. Ioo. Ainsi, en en réduisant suffisamment la vitesse, on peut obtenir une croissance sans hyperplasie chez le rat sevré. Cependant, ce phénomène soulève les questions suivantes : I) quelle est la vitesse de croissance limite permettant d'obtenir une croissance sans hyperplasie? 2) quelque minime que soit la vitesse de croissance, l'hyperplasie ne reprend-elle pas quand l'animal atteint un certain poids, comme le suggèrent les résultats d'une précédente publication (DURAND et al., I967)?

TABLEAU 3

Contenus en protéines, RNA et DNA chez le Rat mâle

a) Soumis à restriction énergétique à partir du poids de $70 \mathrm{~g}$ et empêché de croître au-delà de $100 \mathrm{~g}$

\begin{tabular}{c|c|c|c|c|c}
\hline No du lot & IA & IIA & IIB & IIC & IID \\
\hline $\begin{array}{c}\text { Durée de la restriction } \\
\text { (jours) }\end{array}$ & 0 & 0 & 182 & 365 & 730 \\
& & & & & \\
\hline Poids vif (g) & 69,0 & 100,2 & 100,0 & 100,5 & 98 \\
Protéines totales (g) & 10,4 & 14,7 & 17,2 & 17,0 & 16,4 \\
RNA total ( $\mu \mathrm{M}$-bases) & 586 & 782 & 540 & 485 & 477 \\
DNA total ( $\mu \mathrm{M}$-bases) & 483 & 648 & 469 & 433 & 410 \\
\hline
\end{tabular}

b) Réalimenté

\begin{tabular}{|c|c|c|c|c|}
\hline No du lot & IIIA & IIIB & II IC & IIID \\
\hline $\begin{array}{l}\text { Durée de la restriction } \\
\text { (jours) }\end{array}$ & 0 & 182 & 367 & 730 \\
\hline Poids vif (g) & 596 & 596 & 502 & 419 \\
\hline Protéines totales $(\mathrm{g})$ & 85,2 & 85,6 & 67,9 & 65,2 \\
\hline RNA total ( $\mu$ M-bases) & 1694 & 1679 & 1387 & 1296 \\
\hline DNA total ( $\mu \mathrm{M}$-bases) & 1404 & 1338 & 1103 & 1079 \\
\hline
\end{tabular}


Lorsque la restriction persiste au-delà de 6 mois, et de telle sorte que les rats demeurent à poids constant, le contenu en RNA décroît dans les différents compartiments corporels étudiés, à l'exception des viscères, où il conserve le même niveau. Le contenu en DNA diminue dans tous les cas. Cependant, tant pour le RNA que pour le DNA, les diminutions sont toujours modérées et interviennent à des moments différents suivant le tissu ou l'organe.

Le bilan de l'évolution des contenus de l'organisme entier en acides nucléiques, obtenu en sommant les contenus des six fractions étudiées, met en relief ces diminutions modérées et progressives (tabl. 3). Il faut souligner toutefois que, chez les animaux les plus âgés, on ne sait pas faire la part entre les effets de la persistance de la restriction alimentaire et ceux du vieillissement.

Quoi qu'il en soit, il apparaît clairement qu'un arrêt ou un ralentissement très marqué de la croissance provoque un blocage de l'hyperplasie. Ce blocage peut être suivi de pertes de cellules, variables suivant le tissu considéré et la durée de la restriction alimentaire.

\section{2. - Effets de la réalimentation}

\section{I. Réalimentation et croissance globale.}

Nos résultats montrent que des rats mâles sevrés, empêchés de croître pendant des durées variant de $18 \mathrm{p}$. Ioo à $73 \mathrm{p}$. Ioo de la durée de vie moyenne de l'espèce, n'en ont pas perdu la capacité. Cela apporte une confirmation aux conclusions de OsbORNE et Mendel (I9I4-I9I5) et de McCay et al. (I935), mais infirme celles de WidDowson et MCCANCE (I963) selon lesquelles, chez le Rat, la croissance ne serait plus possible après l'âge de 300 jours.

Il est toutefois possible, sinon probable, que les phénomènes observés soient liés aux conditions expérimentales. Il n'en reste pas moins que, dans les conditions de ce travail, des rats carencés pesant Ioo g à l'âge de 758 jours peuvent encore croître lorsqu'ils sont réalimentés, et atteindre le poids de $420 \mathrm{~g}$; en même temps, la longueur de leur corps augmente de $50 \mathrm{p}$. Ioo et leur contenu protéique corporel est quadruplé. Lorsque la restriction est limitée à 6 mois, le rattrapage, estimé globalement par la vitesse de croissance et la consommation alimentaire, est total ; ceci confirme des données précédentes (DuRand et Penor, 1970). Toutefois, les rats empêchés de croître pendant un ou deux ans n'atteignent pas la taille habituelle de l'espèce, et leur poids maximal qui devrait aisément dépasser $600 \mathrm{~g}$, n'excède pas $500 \mathrm{~g}$ et $420 \mathrm{~g}$ respectivement ; les animaux ne retrouvent pas davantage un appétit normal. Il apparaît donc qu'à partir d'un certain âge, situé entre 6 mois et un an, le rattrapage ne peut être complet; ainsi, il existe bien un effet du temps sur l'aptitude à croître, mais cet effet n'est pas aussi absolu que WidDowson et McCANCE (I963) l'ont affirmé. Par ailleurs, la question se pose de savoir si le manque d'appétit observé chez les animaux réalimentés après de longues durées de restriction énergétique est la causa ou la conséquence de la limitation de l'aptitude à croître.

\section{2. Réalimentation et poids des tissus et organes.}

On peut considérer séparément les animaux empêchés de croître pendant 6 mois (lot IIIB), dont le rattrapage global est total, et les animaux restreints pendant un an et deux ans (lots IIIC et IIID) dont le rattrapage n'est que partiel. 
- Chez le lot IIIB, on distingue, par rapport aux témoins, une infériorité non significative des masses adipeuses, compensée par une légère supériorité des autres fractions corporelles. Dans un précédent travail (DURAND et PENOT, I970) des rats restreints présentaient au contraire des masses adipeuses un peu plus importantes que les témoins. On peut conclure de ces deux expériences successives que la restriction limitée à 6 mois ne modifie pas sensiblement la répartition des tissus et organes.

- Chez le lot IIIC, dont la consommation alimentaire ne dépasse pas $15 \mathrm{~g} /$ jour et dont le poids maximal plafonne à $500 \mathrm{~g}$, la répartition des divers tissus et organes n'est pas très différente de celle que l'on relève chez les témoins ; l'infériorité pondérale de chacune des fractions étudiées par rapport aux fractions témoins correspondantes s'étage de Io,2 p. Ioo pour la peau à $24,2 \mathrm{p}$. roo pour les muscles des membres postérieurs, alors que l'écart global de poids est de $15,7 \mathrm{p}$. Ioo. Les fractions plus désavantagées que la moyenne sont les muscles $(-24,2 \mathrm{p}$. Ioo) et la carcasse (- I $8,5 \mathrm{p}$. IOo). Finalement, la limitation de l'aptitude à croître s'applique à peu près de la même façon à tous les fractions corporelles, si ce n'est pourtant un désavantage un peu plus marqué pour la musculature et le squelette. Chez le lot IIID, au contraire, la répartition des fractions corporelles est largement modifiée, surtout au détriment des tissus adipeux dont la masse n'atteint pas la moitié de ce qu'elle est chez les témoins. La différence pondérale entre les lots empêchés de croître respectivement pendant un et deux ans (lots IIIC et IIID) est imputable pour 75 p. IOO aux tissus adipeux et pour I2 p. roo à la peau; les 13 p. roo restants se partagent entre les quatre autres fractions, dont la part respective varie de o p. Ioo à $5 \mathrm{p}$. Ioo. Le manque à gagner des animaux IIID par rapport aux animaux IIIC provient donc de l'incapacité des premiers d'accroître davantage le poids de leurs dépôts adipeux et de leur peau c'est-à-dire leurs tissus " accumulateurs d'énergie ". Ceci est à rapprocher de la médiocrité de leur appétit, qu'une consommation alimentaire n'excédant pas I4 g suffit à satisfaire.

\section{3. Réalimentation el contenus protéiques des tissus et organes.}

Hormis les tissus adipeux, les diverses fractions corporelles des animaux préalablement empêchés de croître pendant 6 mois (lot IIIB) contiennent autant de protéines que les parties corporelles correspondantes des témoins (lot IIIA). En conséquence, et comme cela apparaît sur le tableau 9, la similitude des contenus protéiques de l'organisme entier des animaux IIIB et IIIA, soit respectivement $85,2 \mathrm{~g}$ et $85,6 \mathrm{~g}$, est remarquable.

Une autre analogie rapproche les lots IIIC et IIID, dont les diverses fractions corporelles renferment également des quantités très voisines de protéines; les organismes entiers de ces deux lots contiennent respectivement $67,9 \mathrm{~g}$ et $65,2 \mathrm{~g}$.

Ainsi un arrêt de croissance de 6 mois ne modifie pas la capacité de l'organisme d'accumuler des protéines. Cependant, cette capacité est amoindrie de façon pratiquement identique pour un arrêt de croissance d'un an ou de deux ans. Il existe donc une durée de l'arrêt de croissance, comprise entre six mois et un an, au-delà de laquelle la récupération protéique ne peut être que partielle ; celle-ci, cependant, présente une limite inférieure déjà atteinte chez les animaux préalablement sousalimentés en énergie pendant un an. En conséquence, le manque à gagner pondéral 
supplémentaire observé chez les animaux préalablement sous-alimentés pendant plus d'un an résulte essentiellement d'une faculté amoindrie d'accumuler des lipides, comme le suggéraient les conclusions du paragraphe précédent.

\section{4. Réalimentation et contenus en acides nucléiques : reprise de l'hyperplasie.}

En ce qui concerne le DNA, l'écart global entre les contenus des organismes des lots IIIA et IIIB ne dépasse pas 4,6 p. Ioo, au détriment des derniers; encore ne distingue-t-on une infériorité réelle qu'au niveau des muscles, de la carcasse et des tissus adipeux, tout comme pour le RNA. Chez les lots IIIC et IIID, les contenus globaux en DNA sont inférieurs respectivement de $2 \mathrm{I}, 4 \mathrm{p}$. Ioo et $23, \mathrm{I}$ p. Ioo au contenu correspondant des témoins; toutes les fractions sont désavantagées et plus particulièrement, une fois encore, les muscles, la carcasse et les tissus adipeux.

Entre les contenus globaux en DNA des lots IIIC et IIID, l'écart est de 2,2 p. Ioo seulement; mais l'examen de chacune des fractions montre que les seules différences notables concernent le foie et surtout les tissus adipeux.

Cependant, la quantité de DNA, stabilisée puis diminuée à la suite de la restriction alimentaire, augmente de nouveau dans chacune des fractions étudiées lorsque les animaux sont réalimentés; globalement, cette quantité est multipliée respectivement par 2,85-2,54 et 2,63 chez les animaux sous-alimentés à partir du poids de $70 \mathrm{~g}$ pendant 6 -r 2 et 24 mois, alors qu'elle est multipliée par 2,90 chez les témoins dont le poids passe de $70 \mathrm{~g}$ à $600 \mathrm{~g}$. D'ailleurs, pour les diverses fractions étudiées hormis les muscles et la carcasse, le coefficient de multiplication de la quantité de DNA est fréquemment du même ordre chez les expérimentaux que chez les témoins passant de $70 \mathrm{~g}$ à $600 \mathrm{~g}$. Il en résulte que le déficit final observé chez les rats préalablement maintenus à poids constant pendant plus de 6 mois est dû en grande partie à la perte cellulaire qui se produit dans de nombreux tissus pendant la période de restriction; cette perte n'est en effet pas compensée par un taux de multiplication cellulaire supérieur à la normale lorsque les conditions alimentaires redeviennent favorables.

Quoi qu'il en soit, à des degrés divers suivant le tissu et la durée de la sousalimentation énergétique, la capacité d'hyperplasie est conservée chez des rats pourtant chronologiquement très âgés. Il n'est cependant pas certain que cette conclusion puisse être étendue sans distinction à l'ensemble des vertébrés supérieurs, dont chaque espèce présente des particularités physiologiques. Ainsi par exemple, dans des conditions normales, l'allongement du squelette peut-il se poursuivre chez le Rat pendant une grande partie de la durée de vie, tandis qu'il parvient à son terme peu après la puberté chez d'autres espèces.

D'une façon générale, les contenus en RNA évoluent parallèlement aux contenus en DNA, de sorte que les rapports RNA/DNA des divers tissus et organes sont pratiquement équivalents chez les réalimentés et les témoins. 


\title{
SUMMARY
}

\author{
INTERRUPTION OF GROWTH IN RAT BY ENERGETIC UNDER NUTRITION \\ FOR PERIODS UP TO TWO YEARS. \\ RESUMPTION OF GROWTH AND CELL MULTIPLICATION
}

Lots of male rats receive severe reduction of energetic intake (carbohydrates and lipids) in the diet at $70 \mathrm{~g}$ of weight ( 4 weeks), and are prevented from attaining more than roo $\mathrm{g}$ of weight for 6,12 or 24 months. At the end of each of these periods, one lot is killed and another rehabilitated The animals prevented from growing are compared to controls of $100 \mathrm{~g}$ (same weight) and $70 \mathrm{~g}$. The rehabilitated animals are killed when they reach $600 \mathrm{~g}$ of weight, or when their weight is maximal. They are compared to $600 \mathrm{~g}$ controls.

The bodies of animals are divided into 6 fractions : liver, muscles of hind members, skin, adipose tissue, internal organs + blood, carcass. Freshweight and protein, RNA and DNA content of each of the six fractions are measured to estimate cell hyperplasia and hypertrophy.

\section{I. - Animals prevented from growing}

- As concerns weight in relation to the normal, energetic underfeeding enhances the musculature, organs and whole skeleton + musculature (carcass), but is unfavorable to liver, skin and especially adipose tissue.

- As concerns protein content, energetic underfeeding enhances liver, musculature, internal organs, whole skeleton + musculature, and is unfavorable to adipose tissue. Skin protein content remains the same in experimental animals and controls of the same weight.

- While RNA and DNA content increases appreciably in controls going from $70 \mathrm{~g}$ to roo $\mathrm{g}$, it remains stable or decreases in the tissue and organs of animals in which growth is very impaired between 70 and roo g, then stopped at that weight. Severe energetic deficiency first causes an arrest of hyperplasia which may be followed, at more or less longtime, by cell loss in some tissues such as adipose tissue.

\section{Rehabilitated animals}

- Growth resumes in all cases studied after rehabilitation. However, while rats previously deficient for 6 months normally reach a weight of $600 \mathrm{~g}$, those previously deficient for one and two years do not attain more than $500 \mathrm{~g}$ and $420 \mathrm{~g}$ of weight, respectively.

- This late growth is accompanied by a resumption of the protein storage. From this point of view, the animals underfed for 6 months catch up almost completely with the controls. This recovery is incomplete, but equivalent, when restriction extends over one or two years.

- RNA and DNA storage resumes also in all cases. Animals underfed for 6 months catch up almost completely, but those deficient for longer periods recover only partially. Nevertheless, hyperplasia ability is kept in prepuberal rats prevented from growing for about $3 / 4$ of the normal life span of the species.

\section{RÉFÉRENCES BIBLIOGRAPHIQUES}

Arnal M., Fauconneav G., Pech R., 1972. Synthèses protéiques in vivo dans divers tissus du Rat en croissance soumis à une réduction de l'apport énergétique de la ration. Ann. Biol. anim. Bioch. Biophys., 12, $9 \mathrm{I}-\mathrm{I} 08$.

Barnes H. R., Neely C. S., Kwong E., Labadan B. A., Slavka F., i968. Postnatal nutritional deprivations as determinants of adult rat behavior toward food, its consumption and utilization. $J$. Nutr., 96, 467-476.

Brown M. L., Guthrie H. A., I968. Effect of severe undernutrition in early life upon body and organ weights in adult rats. Growth, 32, $143 \times 150$. 
Durand G., Fauconneau G., Penot E., 1967. Croissance des tissus du Rat et réduction de l'apport énergétique de la ration ; influence sur la teneur en acides nucléiques, Ann. Biol. anim. Bioch. Biophys., 7, I 45-I55.

Durand G., Fauconneau G., Penot E., ig69a. Répartition des cellules entre les tissus du rat adulte, préalablement soumis à une sous-nutrition énergétique temporaire à deux stades de la croissance. Ann. Biol. anim. Bioch. Biophys, 9, 55-73.

Durand G., Penot E., I969 $b$. Évolution du nombre et de la taille des cellules dans les tissus de la Rate adulte amaigrie à la suite d'une carence énergétique. Croissance compensatrice. Ann. Biol. anim. Bioch. Biophys., 9, 575-587.

Durand G., Penot E., I97o. Effets du maintien à poids constant pendant de longues durées chez le rat sevré. Reprise de la croissance, Ann. Biol. anim. Bioch. Biophys., 10, 385-399.

Durand G., 1973. Effets comparés de restrictions protéiques et de restrictions énergétiques sur les contenus en protéines et en acides nucléiques des tissus du rat en croissance. Ann. Biol. anim. Bioch. Biophys., 13, 399-418.

Elliott D., CheEK D. B., I968. Muscle cell growth in rats with hypoxia and reduced nitrogen. In : Human growth. Edited by D. R. CHEEK, chap. 23. Lea et Febiger, Philadelphia.

Graystone J. E., CheEK D. B., I969. The effects of reduced calorie intake and increased insulininduced calorie intake on the cell growth of muscle, liver and cerebrum and on skeletal collagen in the postweanling rat. Pediat. Res., 3, 66-76.

Hill D. E., Holt A. B., Parra A., CheEk D. B., I97o. The influence of protein-caloric versus caloric restriction on the body composition and cellular growth of muscle and liver in weanling rats. John's Hopkins med. J., 127, I46-163.

Kayser J., Neuman J., Lavollay J., I966. Sur la longévité du rat wistar nourri ad libitum avec un régime semi-synthétique. C. R. Acad. Sci., 262, 2063-2065.

Lister D., McCANCE R. A., 1965. The effect of two diets on the growth, reproduction and ultimate size of Guinea-pigs. Brit. J. Nutr., 19, 31r-319.

Lister D., Cowen T., McCANCE R. A., r966. Severe undernutrition in growing and adult animals, I6. The ultimate results of rehabilitation : poultry. Br. J. Nutr., 20, 633-639.

Lister D., McCANCE R. A., I967. Severe undernutrition in growing and adult animals. I7. The ultimate results of rehabilitation of pigs. Br. J. Nutr., 21, 787-799.

McCay C, M., Crowell M. F., MaYnard L. A., 1935. The effect of retarded growth upon the lenght of life span and upon the ultimate body size. J. Nutr., 10,63-79.

Osborne T. B., Mendel L. B., Igr4. The suppression of growth and the capacity to grow. J. Biol. chem., 18, 95-106.

Osborne T.B., Mendel L. B., Igr5. The resumption of growth after long continued failure to grow. J. Biol. chem., 23, 439-454.

Siperstein D. M., 192.I. The effects of acute and chronic inanition upon the development and structure of the testes in the albino rats. Anxt. Rec., 20, 355-36r.

Stekel A., Sмiтh N. J., r $969 a$. Hematologic studies of severe undernutrition of infancy. I. The . anemia of prolonged caloric deprivation in the pig. Pediat. Res., 3, 320-337.

Stekel A., Smith N. J., r969 b. Hematologic studies of severe undernutrition of infancy. II. Erythropoietic response to phlebotomy by calorie-deprived pigs. Pediat. Res., 3, 338-345.

Widdowson E. M., McCANcE R. A., I 963 . The effect of finite periods of undernutrition at different ages on the composition and subséquent development of the rat. Proc. R. Soc. B., 158, 329-342.

Widdowson E. M., Mavor W. O., McCance R. A., 1964. The effect of undernutrition and rehabilitation on the development of the reproductive organs: rats. J. Endocr., 29, I I9-1 26.

Winick M., Noble A., I966. Cellular response in Rats during malnutrition at various ages. $J$. Nutr., 89, 300-306. 